УДК 371.372.6:51

DOI: $10.35619 /$ iiu.v1i10.162

\author{
Шадюк Ольга \\ кандидат педагогічних наук, доцент, доцент \\ кафедри педагогіки та психології (дошкільної \\ та корекційної) імені проф. Т. І. Поніманської \\ Рівненського державного гуманітарного університету \\ м. Рівне, Україна \\ ORCID: 0000-0001-6120-7759 \\ e-mail: olgapad@ukr.net
}

\title{
ІННОВАЦЙНН ПІДХОДИ ДО ОРГАНІЗАЦІЇ НАСТУПНОСТІ ДОШКІЛЬНОЇ ТА ПОЧАТКОВОЇ ЛАНОК ОСВІТИ
}

Анотація. Забезпечення неперервності здобуття людиною освіти $є$ можливим за умови реалізації принципів перспективності і наступності між суміжними ланками освіти, зокрема дошкільною і початковою. Стаття висвітлює актуальну проблему стратегічних інноваційних підходів до розвитку освіти України в першій половині XXI століття, аспекти нововведень щодо організації безперервної освіти. У статті зроблено акцент на основні форми співпраці ЗДО та НУШ, які реалізують принцип наступності суміжних ланок освіти. Доведено, що різноманітні форми співпраці ЗДО та НУШ позитивно впливають на всебічний розвиток особистості дитини, продовжують, поглиблюють та примножують знання, уміння, навички, набуті на попередньому етапі, оптимізують діяльність педагогів та сприятливо впливають на формування сучасної освітньої системи європейського зразка. Вагомими завданнями сьогодення $\epsilon$ забезпечення наступності змісту дошкільної та початкової освіти, відповідність Базового компонента дошкільної освіти віковим особливостям дітей старшого дошкільного віку та вимогам концептуальних засад реформування Нової української школи. Для вирішення цих завдань учителям доцільно використовувати досвід роботи педагогів закладів дошкільної освіти зі старшими дошкільниками та інші інноваційні підходи.

Ключові слова: дошкільна освіта, початкова освіта, наступність, інновація, навчання, ЗДО, НУШ.

Постановка проблеми. Швидкі темпи розвитку сучасного суспільства, інтенсифікація та гуманізація сфер життєдіяльності людей, новітні підходи до формування особистості через «Я-концепція» спонукають по-новому розглядати освітні осередки формування цілісної особистості із адекватними та морально правильними поглядами на життя. Сьогодення вимагає глибокого аналізу та вивчення усіх прямих та опосередкованих впливів на особистість.

Синхронізація цілей початкової та дошкільної освіти 3 потребами глобалізованих суспільств, управлінські трансформації, модернізація змісту початкової школи та удосконалення змісту Базового компонента дошкільної освіти в Україні, посилення ціннісного потенціалу освіти, розширення шкільної автономії та доступність закладів дошкільної освіти - усі ці й інші інноваційні перетворення у провідних країнах світу $є$ цінними для України в умовах кардинальної реформи початкової школи та дошкільної освіти.

Нова українська школа - це ключова реформа Міністерства освіти і науки. Головна мета - створити школу, у якій буде приємно навчатись і яка даватиме учням не тільки знання, як це відбувається зараз, а й вміння застосовувати їх у житті. Виходячи із цього, надзвичайно важливо на сучасному етапі реформування початкової освіти 
розробити інноваційні підходи до організації наступності дошкільної та початкової ланок.

Аналіз актуальних досліджень. Аспекти інноваційних підходів до організації безперервної освіти уже почасти порушено в працях: І. Беха, Л. Божович, Л. Виготського, Л. Венгера, О. Запорожця, В. Котирло, А. Леонтьєва, М. Лісіної, О. Проскури та ін. Останніми роками XXI століття означений напрям розробляли дотично до методології виховного процесу століття, яке минуло, Л. Артемова, А. Богуш, В. Бондар, Е. Вільчковський, Г. Григоренко, О. Кононко, К. Крутій, Н. Лисенко, 3. Плохій, Т. Поніманська, Т. Степанова, Г. Тарасенко, К. Щербакова, та iн.

Мета статті. Висвітлити та обгрунтувати основні інноваційні підходи до реалізації принципу наступності закладу дошкільної освіти та початкової школи у сукупності філософських, загальнотеоретичних основ розвитку сучасного освітнього простору.

Виклад основного матеріалу дослідження. Сучасний освітній простір вимагає інноваційного підходу до всіх сфер життєдіяльності людини. Змінами у соціокультурній сфері нашого суспільства й реформуванням освітнього простору зумовлено першочерговість проблем забезпечення безперервного особистісного розвитку.

Людину XXI століття вирізняє широта розумових здібностей, швидка адаптаційна здатність до мінливого соціально-економічного довкілля. Сензитивним періодом формування цілісної особистості із здоровим світосприйманням визнано період раннього (від 1 до 3 років), першого (від 3 до 8 років) та другого (від 8 до 11-12 років) дитинства, коли закладається особистісне підгрунтя кожного вихованця, формуються його основи свідомої культури та здорового світоглядного ідеалу. Тому важливо забезпечити наступність у розвитку індивідуально-особистісного потенціалу на етапі дошкільного й молодшого шкільного віку.

Відповідно до законодавства України чинні програми дошкільної й початкової освіти повинні реалізувати наступність в освіті. Однак, ії̈ наступність представлено все ще недостатньо, тому й надалі нагальною залишається проблема сучасної освіти $\epsilon$ потреба в узгодженості між освітніми технологіями, змістом і методами педагогічної діяльності. Вагому роль в аспекті наступності ЗДО та початкової школи відіграють методологічні напрями, в яких враховуються принципи іiі реалізації (розвиток допитливості дошкільника як основи пізнавальної активності майбутнього учня; розвиток різносторонніх здібностей дитини; формування творчої уяви; розвиток комунікативності та ін.) та мають на меті забезпечувати подальший розвиток актуальних напрямів наступності у вихованні особистості у дошкільній та початковій ланках.

Науковці (А. Богуш, М. Вашуленко, В. Галузяк, В. Киричок, В. Кузь, Н. Мойсеюк) стверджують, що наступність у роботі дошкільної і шкільної ланок освіти забезпечує цілісність та ефективність виховного процесу, $є$ показником його послідовності й результативності. Реалізація принципу наступності між дошкільною та початковою шкільною освітою з одного боку спрямована на підготовку дітей до систематичного навчання у школі, а $з$ іншого - на використання у першому класі набутого у закладі дошкільної освіти досвіду. Таким чином, початкова школа має повно і точно враховувати досягнення дітей дошкільного віку, а зміст початкової освіти повинен логічно доповнювати, продовжувати i розширювати зміст дошкільної освіти (Горопаха, 1999).

У наш час в процесі інноватизації освіти постає гостра необхідність комплексного вирішення проблеми наступності, що дозволить забезпечити неперервність і єдину організацію виховного процесу на різних рівнях, послідовне ускладнення знань, способів поведінки і діяльності (Борисова, 1985).

У Міністерстві освіти і науки України неодноразово наголошували, що мета шкільної реформи - створити таку систему освіти, де дитина отримує набір навичок, а 
не багаж знань, які буде важко застосувати в реальному житті. Вчителі, які долучилися до пілотного проекту і запуску НУШ, мали завдання зробити навчання більш інтегрованим, тобто таким, що створює цілісну картину світу, а не обмежує процес однією дисципліною. Тому завданням закладу дошкільної освіти є підготувати дитину до успішної адаптації в НУШ.

Зберігаючи наступність із дошкільним періодом дитинства, початкова школа забезпечує подальше становлення особистості дитини, іiї фізичний, інтелектуальний, соціальний розвиток; формує ціннісне ставлення до держави, рідного краю, української культури, здоров'я, здатність до творчого самовираження, критичного мислення та інше. Виникнення в кожному періоді розвитку дитини нової провідної діяльності (навчальної) не означає зникнення тієї, яка була провідною на попередньому етапі.

Обізнаність учителів початкових класів із програмами, методами, прийомами розвитку, виховання і навчання старших дошкільників у закладі дошкільної освіти та ознайомлення вихователів старших груп 3 освітніми програмами, технологіями навчання, що використовуються у першому класі початкової школи, забезпечить умови для уникнення ситуацій форсування або штучного сповільнення природного темпу розвитку дітей. Змістовий і технологічний аспекти здійснення освітнього процесу в закладах дошкільної освіти і початковій школі мають бути узгодженими 3 урахуванням вікових та індивідуальних особливостей дітей.

Одну 3 ключових позицій у забезпеченні наступності і перспективності в освітньому процесі посідає зв'язок змісту дошкільної і початкової освіти. Він полягає у поступовості й послідовності реалізації чинних програм розвитку, навчання i виховання дітей дошкільного віку та освітньої програми для 1 класу початкової школи. Обов'язкове врахування того рівня розвитку дитини, з яким вона прийшла до першого класу школи, сприятиме органічному, природному збагаченню особистісного розвитку, започаткованому в дошкільному періоді життя, та створить умови для успішного подальшого зростання і переходу дитини 3 першого рівня освіти до наступного.

Відповідно до основних ідей Концепції Нової української школи та положень Державного стандарту початкової освіти з метою забезпечення наступності змісту та уникнення його дублювання в освітніх програмах дошкільної і початкової освіти рекомендується посилити розвивальну і виховну складові освітнього процесу, надати пріоритет соціалізації, моральному вихованню, формуванню мотивів пізнавальної діяльності тощо (Бібік, 2018).

Варто наголосити, що потрібно максимально реалізовувати принцип індивідуалізації навчання без надмірної інтенсифікації інтелектуального розвитку дітей, до якої схиляються окремі педагоги закладів дошкільної освіти та школи, аргументуючи це швидкими темпами соціальних змін. Державним стандартом початкової освіти навчання дитини писемному мовленню (читання, письмо) передбачено в початковій школі. Водночас, неприпустимо штучно уповільнювати індивідуальний темп розвитку дитини, орієнтуючись на «середнього учня». Доцільною $\epsilon$ організація освітнього процесу, орієнтованого на зону найближчого розвитку дитини (Міністерство освіти і науки України, 2018 a).

Удосконаленню і осучасненню освітнього процесу у закладах початкової школи сприятиме відмова від застарілих підходів: фронтальних форм організації освітнього процесу, класичного розташування учнів у класі, статичних поз на заняттях і уроках та інше. Для забезпечення оптимальної рухової активності дітей доцільно передбачити динаміку проведення заняття/уроку (зміну видів діяльності) (Кудрявцев, 2001).

3 метою організації плідної роботи та взаємодії у сфері школи педагогам закладів дошкільної освіти слід активізувати мислення дітей, сприяти свідомому сприйманню і засвоєнню ними знайомого і нового матеріалу, заохочувати до постановки питань, висування припущень, пошуку самостійних рішень, перевірки їх правильності та інше. 
Під час проведення організованої навчально-пізнавальної діяльності важливо систематично використовувати різноманітні класичні та інноваційні педагогічні технології, методи і прийоми, що позитивно зарекомендували себе в сучасній дидактиці, раціонально поєднувати вербальні, наочні та практичні методи.

Важливим фактором модернізації безперервної освіти $є$ створення і реалізація єдиної, динамічної, перспективної системи конструктивних дій, спільних для управлінців, педагогів і батьків та спрямованих на розвиток, виховання і навчання старших дошкільників та молодших школярів. Для сталого функціонування такої системи важливо налагодити взаємодію між закладами освіти (або відповідних структурних підрозділів закладу освіти) на основі угоди про співпрацю, у якій визначається мета співпраці, права і обов'язки кожного закладу. Угода укладається директорами закладів щороку в червні (Зотова, 2002).

Для ефективного обміну досвідом вихователів закладів дошкільної освіти та учителів початкової школи щодо використання ігрових методів і прийомів, форм організації діяльності дітей, системи роботи 3 розвитку мовлення, формування пізнавальних процесів, соціалізації дитини тощо доцільно передбачати індивідуальні та інтерактивні (колективні, колективно-групові, групові) форми методичної роботи (Міністерство освіти і науки України, 2018 a). А саме: взаємовідвідування вчителями та вихователями відкритих занять (інших форм організації освітньої роботи) з дітьми старшого дошкільного віку та уроків у початковій школі; анкетування педагогів закладів освіти з питань забезпечення гармонійного розвитку особистості дитини 3 метою вивчення потреб у підвищенні майстерності; підготовка і проведення спільних педагогічних рад, семінарів-практикумів, засідань «круглих столів», конференцій, консультацій, тематичних виставок тощо; організація роботи спільних методичних об'єднань, творчих груп вихователів закладів дошкільної освіти і вчителів початкової школи; залучення педагогів закладів дошкільної освіти і початкової школи до участі в спільних педагогічних проектах, розроблення методичних рекомендацій і порад; обмін педагогічним досвідом з різних питань щодо реалізації наступності між дошкільною та початковою ланками освіти; сприяння самоосвіті педагогів, підвищення їх фахової майстерності.

Встановлення зв'язку та творчої співпраці між закладом дошкільної освіти і початковою школою на рівні заходів з дітьми - необхідна умова успішного вирішення завдань наступності. Практичний аспект співробітництва у цьому контексті передбачає (Міністерство освіти і науки України, 2018 b): попереднє знайомство вчителів зі своїми майбутніми учнями; відвідування вихователями відкритих уроків, позакласних заходів своїх колишніх вихованців-першокласників 3 метою спостереження за їх розвитком; проведення екскурсій; організацію спільних тематичних виставок дитячих робіт, вернісажів, конкурсів тощо; проведення спільних заходів для дітей старшого дошкільного віку та учнів початкової школи у закладах дошкільної і загальної середньої освіти (театралізованих вистав, відвідування музеїв тощо); спільну участь школярів і старших дошкільників у проектній діяльності та інше.

Інноваційні підходи щодо забезпечення наступності мають здійснюватися педагогічними колективами спільно і системно. Об'єднані зусилля педагогічних колективів закладів дошкільної і загальної середньої освіти та батьківської громадськості забезпечить психологічно виважений та успішний для дитини перехід 3 попереднього рівня - дошкільна освіта, на наступний - початкова освіта.

Висновки і перспективи подальших розвідок. Перехід дитини із закладу дошкільної освіти до школи $\epsilon$ важливим етапом ії життя, який пов'язаний не лише зі зміною середовища іiі розвитку, а й з відповідними процесами самоусвідомлення, зіткненням 3 новими проблемами, відкриттям у собі нових можливостей тощо. Одним дітям це додає піднесеного настрою, відчуття чогось якісного, іншим вселяє ностальгію за звичним життям у дитячому садочку, інколи породжує стресові стани. Тому дуже важливо, щоб у закладі дошкільної освіти, в сім’ї допомогли дитині 
усвідомити, що школа є продовженням того, чим займалася, що опановувала вона у ЗДО. Не менш важливо, щоб із перших днів перебування в школі дитина на конкретних прикладах переконувалася в цьому. Все це стане можливим, коли дотримуватися принципу наступності дошкільної та початкової освіти.

У цьому напрямі наукового вирішення потребують питання змісту сучасної дошкільної та початкової освіти, а також інформаційного, методичного, матеріальнотехнічного забезпечення навчального процесу в НУШ та ЗДО.

\section{СПИСОК ВИКОРИСТАНИХ ДЖЕРЕЛ}

Горопаха, Н. (1999). Наступність дошкільної та початкової шкільної освіти у реалізації принципів розвиваючого навчання. В: Оновлення змісту, форм і методів навчання і виховання в закладах освіти: Наукові записки РДГУ. Рівне: РДГУ, 7, с.7478.

Борисова, 3. (1985). Наступність у навчально-виховній роботі дитячого садка $i$ школи. Київ: Рад. школа. 142с.

Бібік, Н. (2018). Нова украӥнська школа: порадник для вчителя. Київ: Літера ЛТД. $160 \mathrm{c}$.

Міністерство освіти і науки України, (2018 а). Державний стандарт початкової освіти, [online]. Режим доступу: https://nus.org.ua/news/uryad-opublikuvav-novyjderzhstandart-pochatkovoyi-osvity-dokument/ [Дата звернення 24 вересня 2019]

Кудрявцев, В. (2001). Дошкольное и начальное образование - единый развивающий мир. Дошкольное воспитание, 6, с. 58-66.

Зотова, Т. (2002). Проблема преемственности в системе «ДОУ - начальная школа». В: Наука и образование: проблемы и перспективы. с. 15-18.

Міністерство освіти i науки України, $(2018$ b). Інструктивно-методичні рекомендації щодо забезпечення наступності дошкільної та початкової освіти. Учитель початкової школи. с. 1-4.

\section{REFERENCES}

Horopakha, N. (1999). Nastupnist doshkilnoi ta pochatkovoi shkilnoi osvity u realizatsii pryntsypiv rozvyvaiuchoho navchannia [Continuity of Preschool and Primary School Education in the Implementation of the Principles of Developmental Learning]. V: Onovlennia zmistu, form i metodiv navchannia $i$ vykhovannia $v$ zakladakh osvity: Naukovi zapysky RDHU. Rivne: RDHU, 7, s.74-78. (in Ukrainian)

Borysova, Z. (1985). Nastupnist u navchalno-vykhovnii roboti dytiachoho sadka i shkoly [Continuity in the Educational Work of Kindergarten and School]. Kyiv: Rad. shkola. 142 s. (in Ukrainian)

Bibik, N. (2018). Nova ukrainska shkola: poradnyk dlia vchytelia [New Ukrainian School: Teacher Advisor]. Kyiv: Litera LTD. 160 s. (in Ukrainian)

Ministerstvo osvity i nauky Ukrainy, (2018). Derzhavnyi standart pochatkovoi osvity [State Standard of Primary Education], [online]. Rezhym dostupu: https://nus.org.ua/news/uryad-opublikuvav-novyj-derzhstandart-pochatkovoyi-osvitydokument/ [Data zvernennia 24 veresnia 2019]. (in Ukrainian)

Kudriavtsev, V. (2001). Doshkolnoye i nachalnoye obrazovaniye - yedinyj razvivayushchij mir [Preschool and Primary Education - a Uniform Developing World]. Doshkolnoye vospitaniye, 6, s. 58-66. (in Russian)

Zotova, T. (2002). Problema preemstvennosti v sisteme "PEI - nachalnaya shkola" [The Problem of Continuity in the System of "Preschool Educational Institution - Primary School"]. V: Nauka i obrazovaniye: problemy i perspektivy. s. 15-18. (in Russian)

Ministerstvo osvity i nauky Ukrainy, (2018). Instruktyvno-metodychni rekomendatsii shchodo zabezpechennia nastupnosti doshkilnoi ta pochatkovoi osvity [Instructional and Methodological Recommendations for Ensuring Continuity of Preschool and Primary Education]. Uchytel pochatkovoi shkoly, s. 1-4. (in Ukrainian) 


\title{
INNOVATIVE APPROACHES TO THE ORGANIZATION \\ OF THE CONTINUITY OF PRESCHOOL AND PRIMARY EDUCATION
}

\author{
Olha Shadiuk \\ Candidate of Pedagogical Sciences, Associate Professor, \\ Associate Professor at the Department of Pedagogy \\ and Psychology (Preschool and Correctional) \\ named after Professor T.Ponimanska, \\ Rivne State University for the Humanities \\ Rivne, Ukraine \\ ORCID: 0000-0001-6120-7759 \\ e-mail: olgapad@ukr.net
}

\begin{abstract}
One of the main directions of the state educational policy in Ukraine is recognized modernization of the preschool education system, taking into account the principles of democratization, humanization, and individualization of the pedagogical process. In its basis it is fixed personality growth of every child taking into account her capabilities, individual features of physical and psychological development, the State requirements to the level of formed, developed, breeding of a child 6 (7) years before her entering school certain positions of the base component of preschool education. Providing of continuity of receiving by the man of education is possible taking into account the principles of perspective and the adjacent links of education in particular preschool and initial ones are traced. The article lights up the issue of the strategic innovative approach to the development of education in Ukraine, aspects of innovations regarding to organization of continuous education. In the article an accent is done on the basic forms of collaboration of institutions of preschool education and new Ukrainian school, which will realize principle of the continuing education. It is proved that the various forms of collaboration of establishment of preschool education and new Ukrainian school positively influence on comprehensive development of a child, continue, deepen and increase knowledge, ability, skills, acquired in the previous stage, optimize activity of teachers and favorably influence on forming of the modern educational system of the European standard. The important tasks of modern life is providing of the following of maintenance of preschool and elementary education, in accordance with the base component of preschool education to senior preschool age children and requirements of conceptual principles of New Ukrainian school. To decide these tasks it is recommended for teachers in their work with children to use the experience of preschool teachers and other innovative approaches.
\end{abstract}

Keywords: preschool education, elementary education, continuity, innovation, training, institution of preschool education, new Ukrainian school.

Стаття надійшла до редакиії 02.10.2019 р. 